\title{
Evidences by Multiscale Analysis and 2D3/4 Models from the Magnetic Anomalies and Iron Mineralization (BIF) over the DJADOM-ETA Area, Southeastern Cameroon
}

\author{
Justine Yandjimain ${ }^{1}$, Théophile Ndougsa-Mbarga ${ }^{1,2^{*}}$, Arsène Meying3 ${ }^{\text {, Paul Claude Ngoumou² }}$ \\ ${ }^{1}$ Postgraduate School of Sciences, Technologies \& Geosciences, University of Yaoundé I, Yaoundé, Cameroon \\ ${ }^{2}$ Department of Physics, Advanced Teacher's Training College, University of Yaoundé I, Yaoundé, Cameroon \\ ${ }^{3}$ Department of Applied Geophysics, Geology and Mining Exploitation College, University of Ngaoundéré, Ngaoundéré, Cameroon \\ Email:*tndougsa@yahoo.fr
}

How to cite this paper: Yandjimain, J., Ndougsa-Mbarga, T., Meying, A. and Ngoumou, P.C. (2020) Evidences by Multiscale Analysis and 2D3/4 Models from the Magnetic Anomalies and Iron Mineralization (BIF) over the DJADOM-ETA Area, Southeastern Cameroon. Open Journal of Earthquake Research, 9, 19-32.

https://doi.org/10.4236/ojer.2020.91002

Received: September 21, 2019

Accepted: January 28, 2020

Published: January 31, 2020

Copyright (c) 2020 by author(s) and Scientific Research Publishing Inc. This work is licensed under the Creative Commons Attribution International License (CC BY 4.0).

http://creativecommons.org/licenses/by/4.0/ (c) (i) Open Access

\begin{abstract}
The Magnetic method is one of the best geophysical techniques used to delineate subsurface structures. This study was conducted to investigate the basement faulting and ore mineralization into the overlying geological cover. The GEOSOFT v8.4 software was used to process the data. Upward continuation of the residual magnetic intensity map at various altitudes and the maxima of their horizontal gradient magnetic were used to highlight faults from shallow to deep, as well as, their dips and mineralization zones. The faults with the directions E-W, ESE-WNW and ENE-WSW are identified confirming the result of [1]. This study also reveals that, the layer is affected by faults propagating from the basement upwards into the cover. Our results added additional information to the knowledge of the geological structure and the mineral resources potential in the study area. Based on the 2D3/4 modeling, the Dja Fault (DF) is revealed and highlighted sub-area marked by a magnetite/or hematite dolerite, schist and sandstone blocks, which show strong magnetization. Specifically, in this area, models are made of BIF (bounded iron formation) and BIQ (bounded iron quartzite) as dominant minerals.
\end{abstract}

\section{Keywords}

Aeromagnetic Anomalies, Multiscale, Mineralization (BIF (Bounded Iron Formation), BIQ (Bounded Iron Quartzite)), HMG (Horizontal Gradient Magnetic), Faults 


\section{Introduction}

Cameroon is underlain by Precambrian rocks, Cretaceous and Cenozoic sediments and volcanic formations [2]. Cameroon in general and its south-eastern area are a zone where geological and geophysical investigations are carried out permanently. But detailed investigations in the south-eastern zone are not available. The study area is in the southern region of Cameroon between the meridians $13^{\circ} 50^{\prime}$ and $14^{\circ} 20^{\prime}$ East and parallels $2^{\circ} 10^{\prime}$ and $2^{\circ} 35^{\prime}$ North, with an average altitude of $850 \mathrm{~m}$. The purpose of this study is to highlight some sub-zone of mineralization and the basement structural system with the use of the HMG maxima method applied to aeromagnetic data. Aeromagnetic data analysis is useful to determine the properties of the magnetic basement beneath the cover [3]. One of the important parameters in quantitative interpretation is the depth of the anomalous body [3]. In mining exploration, the basement depth obtained through the empirical method based on upward continuation, horizontal gradient and maxima of horizontal gradient is required. Aeromagnetic survey maps showing variations of the geomagnetic field and magnetic anomalies are interpreted to be a function of the rock's magnetization. This observation is often explained using magnetic profiles and maps of magnetic lineaments [4]. The magnetic investigation done by [1] is used the tilt angle method and has highlighted two major lineaments: ESE-WNW and ENE-WSW. The study realized by [1] is adjacent to [5] where the same directions of lineaments are signaled in the eastern part of our study area. The continuity of the prolongation Northwards of our zone is documented in an audio magnetotellurics and in aeromagnetic analyses carried out respectively by [6] and [7]. Magnetic minerals can be mapped from the surface to greater depths in crustal rocks depending on the dimension, shape, and magnetic properties of the rock. The mineralization (BIF) is highlighted by $2 \mathrm{D} 3 / 4$ modeling.

\section{Materials and Methods}

\subsection{Geology and Tectonic Setting}

The geology of the study area (Figure 1(b)) is part of the Ntem complex and was first elaborated by [8]. The polygon is the Djadom-Eta area where acquisition of data has been conducted. The Neoproterozoic Panafrican mobile belt covers part of the Yaoundé Group to the North, and the Ntem Complex to the south. The Ntem complex represents the northern part of the Congo Craton (CC) in Central Africa [9]. [10] considered the Ayos, Mbalmayo and Bengbis formations as belonging to the Precambrian mean age. The area is also included in the Dja series and is comprised of the tillitic, doleritic and Bek complex. It belongs to the meta-sediment's series of Dja-Ayos-Mbalmayo-Bengbis [11]. According to [8], the geology of the area is dominated by the extension of the Archean Congo Craton (Ntem Complex $\sim 3 \mathrm{Ga}$ ), which is composed of chlorite-greenschist, mica-schist with muscovite, and the interstratified lentils of quartzite. The doleritic complex (sills and dykes) is composed of greenschist, the quartzite mylonitic, 


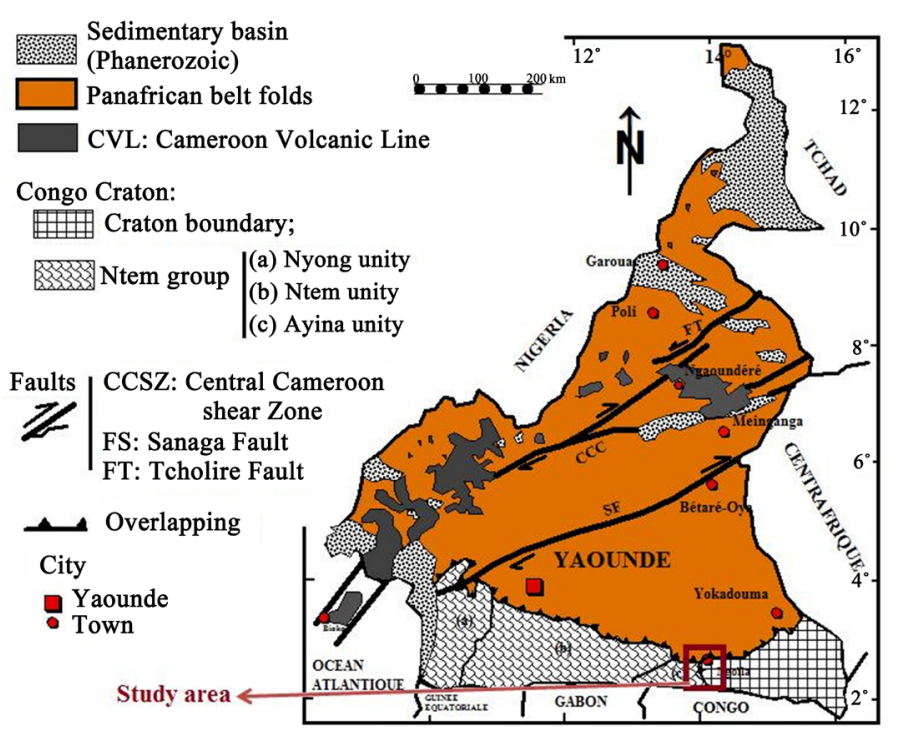

(a)

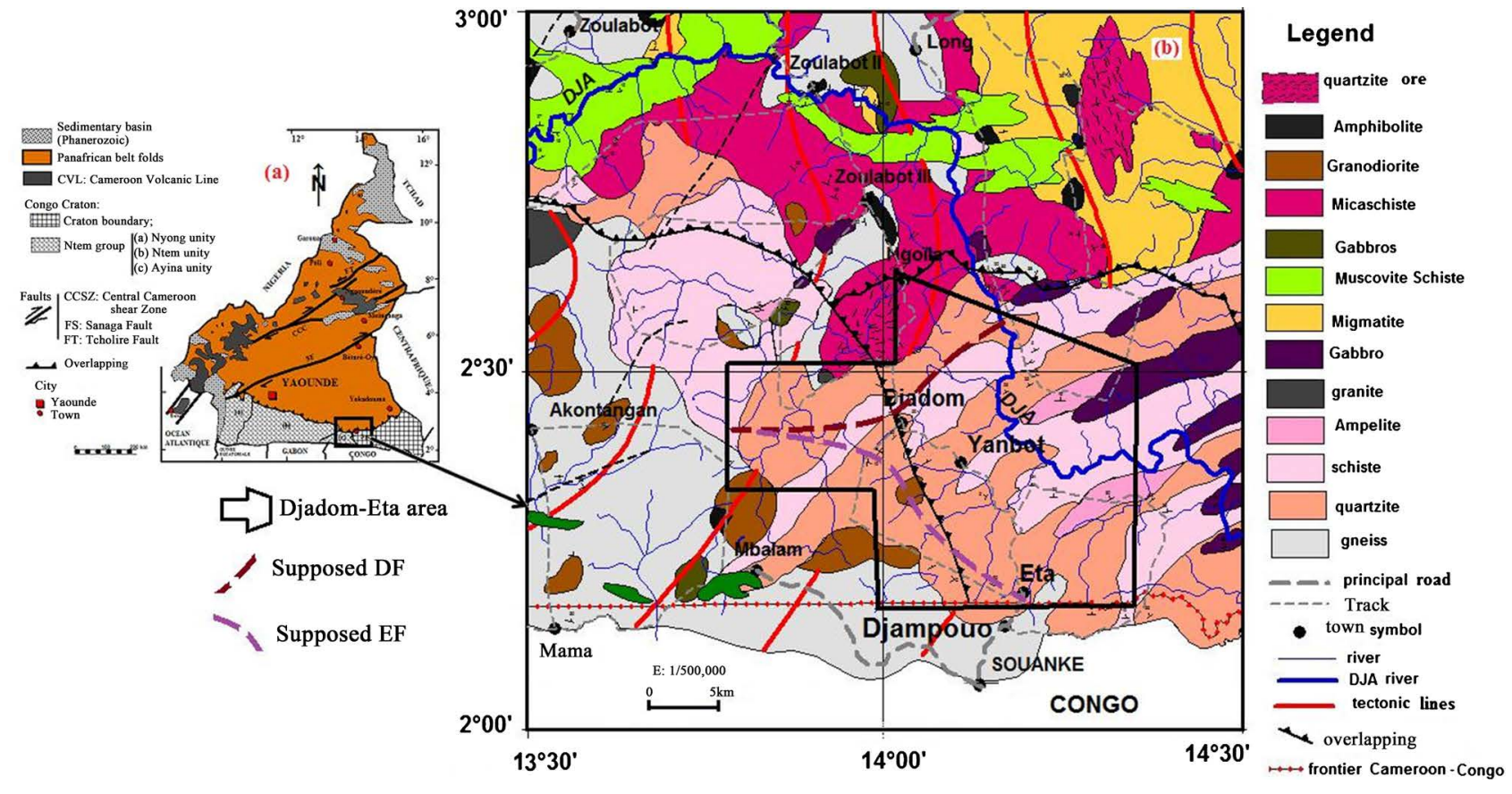

(b)

Figure 1. (a) Important geological formations of Cameroon [12]; (b) Geological map of the DJADOM-ETA area southeastern Cameroon (modified after [8]. The polygon is a Djadom-Eta area investigation; with the locations of Djadom Fault (DF) and Eta Fault (EF).

dolerites and gabbros. The Bek complex is made up of quartzite sandstone, clay-schist and blue schist. The garnet's basement complex series is mainly composed of ectinites (gneiss and amphibolite), migmatites (granite of magmatic) and intrusive rocks (granite and granodiorite). The magnetic study done by [1] in this area shows the presence of bifurcations, accompanied by deformations. The same authors highlight two major faults: ESE-WNW and ENE-WSW, where first could be called the geological structure of Eta and the second could 
be associated with an open synclinal transposed on vertical foliations in the Djadom axis. These authors deduced that the Djadom fault is quasi-parallel to the northern limit of the Congo Craton (CC) and parallel to the Sanaga Fault (SF) and the Central Cameroon Shear Zone (CCSZ) (Figure 1(a)). Geologicaly, [1] have documented the intrusion of sandstone ochre quartz and schist of the Bek complex, the doleritic complex, the silver micaschist and ore quartzite in the Ntem complex. Tectonically, [1] show a base strongly affected by tectonic which characterizes the transition between the $\mathrm{CC}$ and the belt from folds of the Pan-African (Figure 1(a)). Also, the presence of network of lineaments characterizes the subsurface undulation in this study area. The northern boundary of the Congo Craton is defined to be starting from $3^{\circ} 7^{\prime} \mathrm{N}$ of West to $3^{\circ} 75^{\prime} \mathrm{N}$ of East. Its depth is ranged from $2.6 \mathrm{~km}$ to $0.1 \mathrm{~km}$ with a an ENE-WSW direction and NW slope varying from $30^{\circ}$ to $60^{\circ}$ [7].

Peak of deposition that took place in the Proterozoic could probably be explained by the globally recognized intense crust-forming processes in the Early Proterozoic era. The origin of the younger Neoproterozoic ages is tied to various lithologies within the northern mobile belts of the Adamawa-Yade massifs and correlates with Neoproterozoic sedimentation ages in the Yaoundé, Lom and Poli series [13]. In the northwest of the study area, [14] [15] the banded iron formation (BIF) is situated in the CC the west of the study area. [13] characterizes meta-sediment associated with Banded Iron Formations (BIFs). This present of BIF confirm the rapport of CMC exploration in 2012 [16]. BIFs were formed by contemporaneous events of active sediment supply and the venting of a hydrothermal fluid source. BIFs within the Ntem Complex at the northern edge of the Congo Craton are intercalated with meta-sandstones and meta-siltstones. Petrographic studies indicate that the meta-sandstone has quartz grains that are elongated. The rock has a class supported fabric dominated by quartz grains. The meta-siltstone on the other hand shows a strong diagenetic foliation defined by distinct sub-parallel quartz-rich bands which are oblique to mica-rich bands.

\subsection{Data Source and Acquisition}

The aeromagnetic data set used in our study was acquired by the "Compagnie Minière du Cameroun" SA during the year 2012. An airborne geophysics with $2000 \mathrm{~m} \times 200 \mathrm{~m}$ line spacing was conducted on the Upper Nyong Division of the East Region of Cameroon in February 2012. The Survey was carried out by an AS350B2 helicopter, with a total of 11305 lines by kilometer of magnetic data and the flight was trending NE-SW. The survey was carried out at a nominal terrain clearance of $100 \mathrm{~m}$ which was monitored by radar altimeter with an accuracy of $\pm 20 \mathrm{~m}$.

\subsection{Methods of Study}

\subsubsection{HMG Approach}

The Horizontal Magnetic Gradient (HMG) technique is based on the evaluation 
of the horizontal derivative of the residual magnetic field [17] [18]. This method is used to estimate the horizontal contacts and depths of geological structures. It requires the greatest number of assumptions about the sources, but it minimizes the noise contained in data during the aeromagnetic survey, because it only requires the calculation of the two first-order horizontal derivatives of the magnetic field [17]. The maxima of the HMG map were evaluated at different altitudes to delineate associated crustal faults. The HMG peaks are over magnetic contacts on the assumptions that the regional magnetic field and source magnetizations are vertical [17]. The ridges or maxima of the horizontal derivative are recognized generally as being good locators of vertical body. In contrast, if the structures are not vertical (i.e., dipping structures), the maxima are displaced in the direction of the dip as the height of the upward continuation increases. This method has been used to characterize some lineaments related to major tectonics of the study area. The maps are obtained by using the software Geosoft of Oasis Montaj v.8.4. The specific upward continuation altitudes $(750,1500,2250$, $3000,3750 \mathrm{~m}$ ) helped to observe the magnetic, structural, and dip from the surface to various depths. The choice of such altitudes is based on geological constraints to clearly indicate the linear structure. According to [17] [19], gradient analysis focuses on the maxima that coincide with the contact zones between structures, faults and lithological contacts. If $M$ is the residual magnetic field, then the amplitude of the Horizontal Magnetic Gradient ( $H M G$ ) following the $x$ and $y$ direction technique is given by (1):

$$
H M G=\sqrt{\left(\frac{\partial M}{\partial x}\right)^{2}+\left(\frac{\partial M}{\partial y}\right)^{2}}
$$

The $H M G$ technique is used to calculate the horizontal gradient associated with the upward continuation of the residual magnetic field [1] at various altitudes. This step is followed by the calculation of the horizontal gradient maxima for each level, yielding the maxima progressive migration, which reveals the dip direction of the inferred faults. This technique enables the location of discontinuities and determines their dip. According to [20], the depth $\left(z_{0}\right)$ the plan from the observation of the anomalies sources is inferior of the upward continuation altitude and could be estimated as the half of the altitude $(h) . h=2 z_{0}$ then $z_{0}=$ $h / 2$. (3)

\subsubsection{Dip and 2D3/4 Modeling Approaches}

The dip of a linear structure (feature) represents the angle $\alpha$ between the plane of the structure and the horizontal plane [21]. For effective modeling of the geological structure, a study of the basement is required.

Thus, certain parameters (position, depth and contrast of susceptibility) of the source must be carried out starting from the knowledge of the structure. These priorities parameters must determine by the HGM method. The 2D3/4 modeling is an appropriate method for modeling the base, seams and semi-infinite contacts. The choice of the representation of profile depends on the form and the 
position of the sources. On the residual map, the profiles are drawn perpendicular to the anomalies (Figure 2) using Geosoft's "GMSYS" module.

\section{Results}

\subsection{Residual Magnetic Intensity of the Study Area}

The Residual Magnetic Intensity (RMI) map (Figure 2) shows inferred composition of the magnetic signature of all the magnetic sources. The effects of the surface structures are masked by those of the underlying structures. The distributions of the anomalies are smoother and have large geological wavelengths. This wavelength with the positive anomalies has the big waves of ESE-WNW direction mark the second main fault on the ETA axis opposite to those ENE-WSW in the Djadom axis highlight by [1]. The main fault on Djadom axis is interpreted as an intersected lineament and those on the Eta axis represented by an entrainment lineament.

\subsection{Maxima Horizontal Magnetic Gradient upward Continuous from $750 \mathrm{~m}$ to $3750 \mathrm{~m}$}

In order to obtain a clear view of the progressive propagation of the basement faults into the overlying magnetized layers, the residual map of the magnetic field is upward continuation at the different altitudes, and the horizontal gradient maxima were calculated for each level (Figure 3). The maxima of the HGM from 750 to $3750 \mathrm{~m}$ altitude are displayed on the residual map (see Figure 3 ). Each upward continued altitude corresponds to source depths of 375,750 , 1125,1500 and $1875 \mathrm{~m}$ respectively. The superposition of the magnetics maxima from 750 to $3750 \mathrm{~m}$ of the altitudes correlate strongly. The disposition of these maxima gives an idea of the geological contacts of the zone. Generally, most of

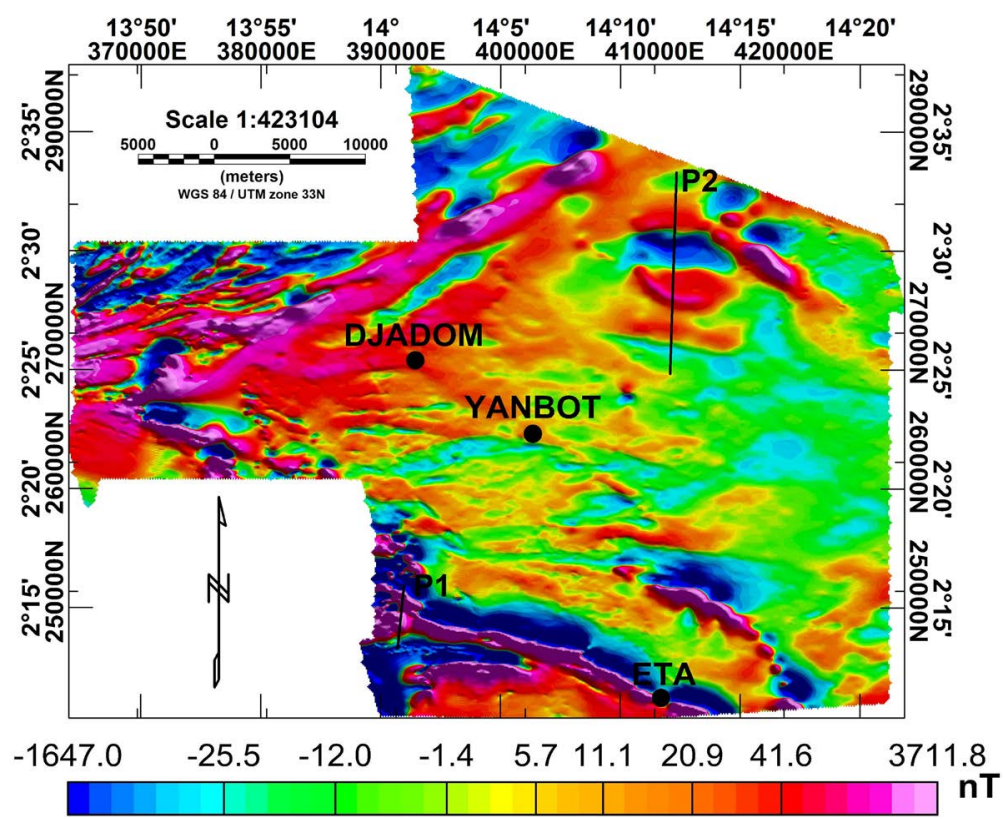

Figure 2. RMI map of the study area [1]. 


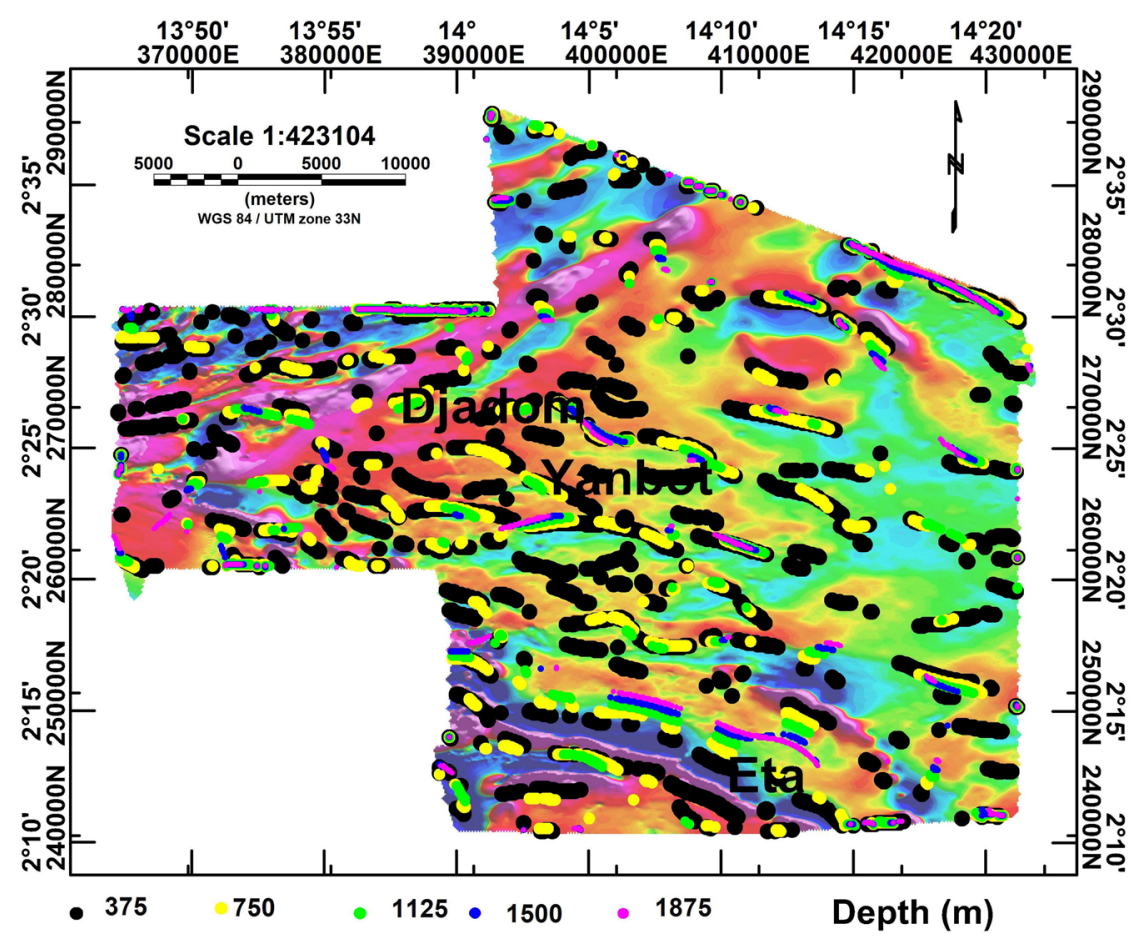

Figure 3. Comparison between the location of the HMG maxima from 750 to $3750 \mathrm{~m}$ altitude and the residual magnetic field.

the elongated faults inferred within the geologic provinces were basement-evolved faults, and movements along these faults might have led to some high angled faults within the sediments. The shallow faults mostly have same direction as deeper faults located in the basement, implying that both geological structures have been produced during the same tectonic processes. This shows that the pattern of the structures in the subsurface unit of Ntem is likely to be initiated by the underlying basement structural features. The identified fault trends are attributed to extensional tectonics that created the complex of Ntem. The interpretation of these maxima is based on some assumptions. If the maxima at the different depths are parallel and overlapped, the gradients are vertical. Instead, if the maxima at the different depths are parallel and not overlapped, the gradients are quasi-horizontal. All these gradients mark contact linear structures.

\subsection{Lineaments Dip Approach and Mineralization Zones}

The disposition of the maxima allows estimating the location of the magnetic structures (Figure 4). These structures start from shallow to approximately 1875 $\mathrm{m}$ depth and are often hidden beneath the geological formations. The dispositions of the features present three directions ESE-WNW (axis ETA), WSW-ENE (axis Djadom) and E-W (axis Yanbot). Many of these features correlate with those raised by [1] who applied the tilt angle method. We note the presence of the Quasi-horizontal features (F14, F19, F3, F27, F9, F6, F18) and the quasi-vertical features (F1, F12, F16, F17, F7, F21, F26, F25, F23, F11, F10, F13, F20, F8, F5, F24) (Table 1). All of these are along the vertical and horizontal 


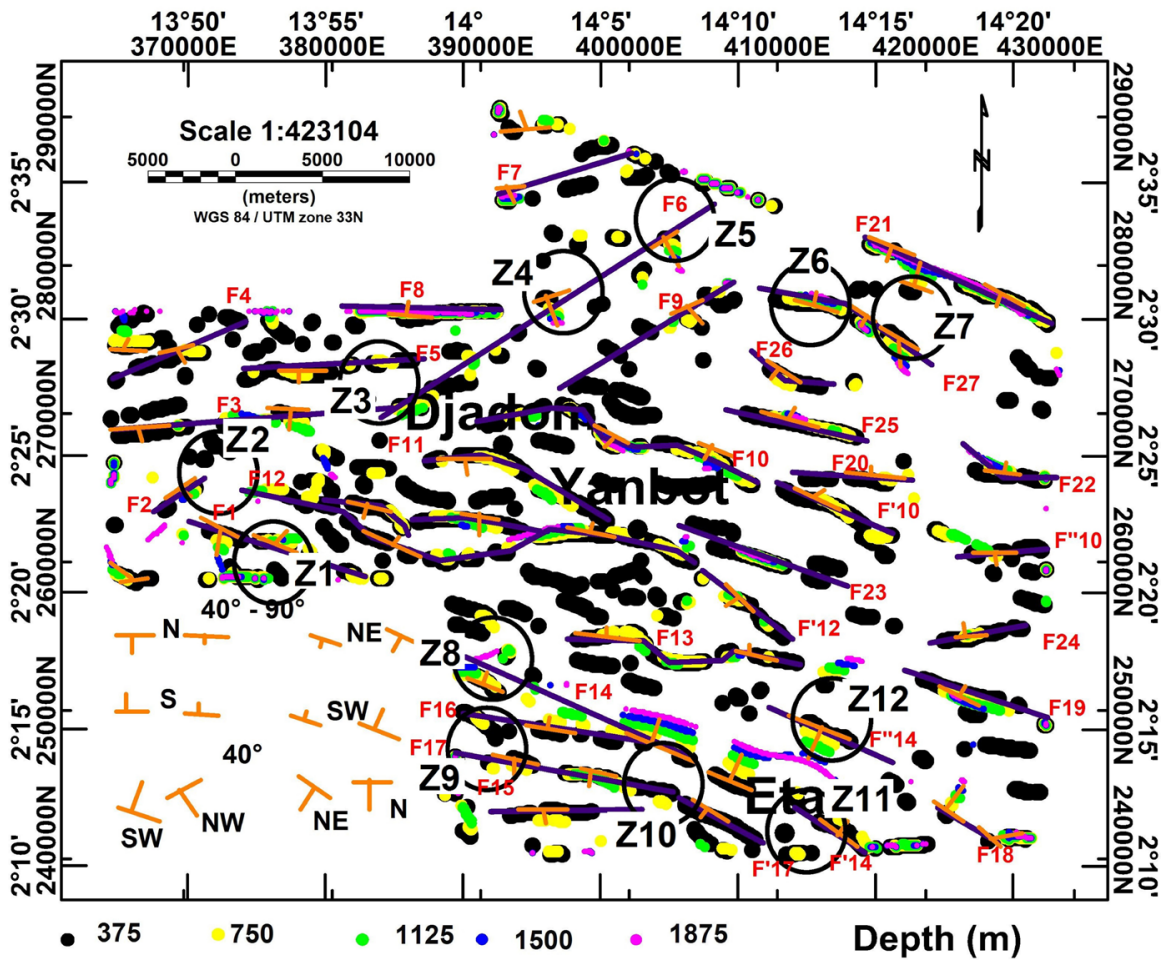

Figure 4. Map showing the depths of the HMG from 375 to $1875 \mathrm{~m}$ superimposed Lineaments (blue lines), Dip approach and possible point drilling (circles).

Table 1. The interest zones and dip directions of some of the inferred propagated faults in the study area.

\begin{tabular}{|c|c|c|c|c|c|}
\hline Direction of Faults & Faults & Dip & $\begin{array}{l}\text { Dip angle } \\
\text { value }\end{array}$ & Orientations & $\begin{array}{c}\text { interest } \\
\text { Zones }\end{array}$ \\
\hline \multirow{6}{*}{ ESE - WNW } & $\mathrm{F} 1$ & Quasi-Vertical & $40^{\circ}-90^{\circ}$ & SW & $\mathrm{Z} 1$ \\
\hline & F17 & Quasi-Vertical & $40^{\circ}-90^{\circ}$ & $\mathrm{N}, \mathrm{S}$ & $\mathrm{Z9}$ \\
\hline & $\mathrm{F} 21$ & Quasi-Vertical & $40^{\circ}-90^{\circ}$ & NE, SW & $\mathrm{Z7}$ \\
\hline & F'14 & Quasi-Vertical & $40^{\circ}-90^{\circ}$ & SW & $\mathrm{Z} 12$ \\
\hline & F14 & Quasi-Horizontal & $<40^{\circ}$ & SW & $\mathrm{Z} 8, \mathrm{Z10}$ \\
\hline & F"14 & Quasi-Horizontal & $<40^{\circ}$ & $\mathrm{NE}$ & $\mathrm{Z} 11$ \\
\hline \multirow{3}{*}{$E-W$} & F25 & Quasi-Vertical & $40^{\circ}-90^{\circ}$ & S & $\mathrm{Z} 6$ \\
\hline & F10 & Quasi-Vertical & $40^{\circ}-90^{\circ}$ & $\mathrm{N}, \mathrm{NE}$ & $\mathrm{Z3}$ \\
\hline & F26 & Quasi-Vertical & $40^{\circ}-90^{\circ}$ & $\mathrm{NE}$ & $\mathrm{Z6}, \mathrm{Z7}$ \\
\hline \multirow{6}{*}{ WSW - ENE } & F3 & Quasi-Vertical & $40^{\circ}-90^{\circ}$ & $\mathrm{N}$ & $\mathrm{Z} 2$ \\
\hline & F7 & Quasi-Vertical & $40^{\circ}-90^{\circ}$ & $\mathrm{N}$ & $\mathrm{Z} 4$ \\
\hline & $\mathrm{F} 4$ & Quasi-Vertical & $40^{\circ}-90^{\circ}$ & NW & $\mathrm{Z} 2$ \\
\hline & $\mathrm{F} 2$ & Quasi-Vertical & $40^{\circ}-90^{\circ}$ & SE & $\mathrm{Z1}, \mathrm{Z} 2$ \\
\hline & F5 & Quasi-Vertical & $40^{\circ}-90^{\circ}$ & $S, N$ & $\mathrm{Z} 3$ \\
\hline & F6 & Quasi-Horizontal & $<40^{\circ}$ & $\mathrm{SE}$ & $\mathrm{Z4}, \mathrm{Z} 5$ \\
\hline
\end{tabular}


gradient. To the NE of Yanbot, the dispositions of these features produce the so-called "Dja Fault". Along the Eta axis, geological structures F14, F16, F17 are converging toward the SW which meets ruptures joining the displacement F'14 so producing a fracture around the Eta. The Fault on axis Djadom, revealed by the tilt angle method [1] is observed.

The plotted maxima allow defining the location of superficial linear features as related to the trend of the deep faults in the basement layer. This shows the orientation of the dip of each lineament controlled from the basement into the shallow sedimentary covers. According to the dips and their directions of dip (Table 1), there are features with dip lower than $40^{\circ}$, SW and NW directions; features with dip ranging between $40^{\circ}$ and $90^{\circ}$ south, north and SW direction (Figure 4). This last group is more significant for mining exploration. They are more suitable where the dip is higher than $40^{\circ}$ and lower than $90^{\circ}$. The degree of importance (in depth) of inferred faults is determined by the continued presence of the local maxima with increase of the altitude.

The meeting of the maxima and dip direction mark the mineralization zones (zone of possible drilling). These zones are indicated by circles on the map (see Figure 4). There is a high correlation between the locations of the deep and shallow faults. This suggests a tectonic link between the basement and the overlying sedimentary column. Structural analysis of the basement faults propagation can advance the understanding of the overlying shallow geological structures for possible BIF system passage and accumulation of an area as revealed by [5] to the SW of our study area.

The results achieved about deep fault propagation allow expanding the knowledge of the regional geological setting, representing valid information to improve geological modeling of the BIF and BIQ areas. The join of the maxima or the abrupt change of dip of maxima marks the possible point drilling (circle in Figure 4). 12 points are possible in the study area. These points belong to the weak zones which are the zones of shearing, fractures and faults outlined in the preceding paragraphs.

\subsection{D3/4 Modeling}

The different models are done with the parameter considerations: the direction of the profiles which must be perpendicular to the directions of the lineaments and the axis of the anomaly, the inclination $-22.78^{\circ}$, the declination $-1.08^{\circ}$ and the mean of the mean of the geomagnetic field tick 33,128.16 nT.

A structural interpretation of the profiles $1 \& 2$ (Figure 5 and Figure 6) reveals the domes in the lower part of the model, probably produced by significant vertical deformations. These thick gneissic domes in the basement are known as the "metamorphic core complex". These models enable an understanding of why the geological map of the area shows geological formations resulting from the layer of the Yaoundé group. These formations are related to a continental subduction. Thus, there are networks of faults in this zone indicating the direction 




Figure 5. Magnetic model along the profile 1. Quartz Mica-Schist (QMS), Banded amphibole (BAM) S = Susceptibility.

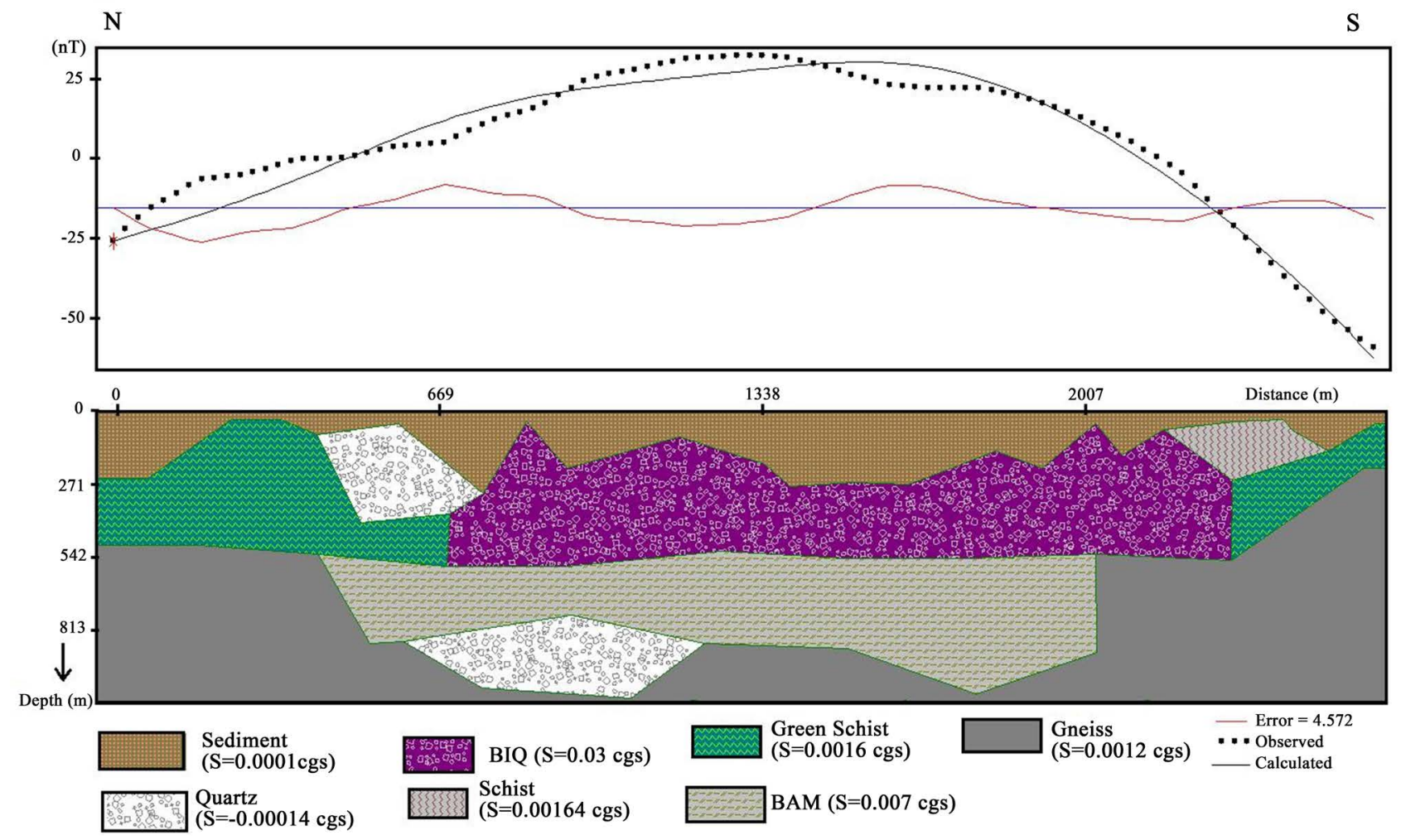

Figure 6. Magnetic model along the profile 2. Banded Iron Formation (BIF), Banded Iron Quartz (BIQ), Banded amphibole (BAM) S = Susceptibility. 
of movement of the layers.

Geologically, these profiles show that the study area has significant magnetite content, since the layers formed by the BIF and the BIQ are the most dominant, owing to their extensions and their intrusions into the green schist rocks. The BAM observed in the model goes a few kilometers into the gneiss and is intruded in green schist. According to geological data [8], this type of amphibole is known as a green amphibole. The sedimentary column is much more significant along the Djadom axis because the sedimentary stratum is thicker along the latter.

\section{Discussion}

The magnetic lineament maps of the basement and the overlying sedimentary layer (Figure 3) consist of major and minor inferred faults. Most of these inferred lineaments are the Djadom fault that is parallel of Sanaga Fault as highlighted by [1]. The structural map shows a network of lineaments in our study area can be considered as the extension of the faults revealed by [5] in the eastern part of our study area. The continuity of this prolongation Northwards of our zone is documented in the audio magnetotellurics study done by [6] and in aeromagnetic study done by [7]. The structural features that trend in the same direction are likely to be produced by the same tectonic processes. This shows that the pattern of the structures in the subsurface unit of Ntem is likely to be initiated by the underlying basement folding. The fractures and the Dja Fault highlight in this study confirm that this area is crossed by Central Africa Belt. Most of the lineaments, interest zone, dips and their orientations are classified in $\mathrm{Ta}$ ble 1 . The dipping between 40 and 90 degrees is more significant for mining exploration. This is in accordance with the CMC 2012 [16] information report, where dipping exploration is 70 to 90 degrees. The magnetic dips highlighted are correlated with the geological dips. The interpretation of the superposition of lineaments leads to discordance marked by shear zones. These fractures and shear zone indicate the weakness sub-areas which are possible high mineralization places. Strong magnetization of rocks can be associated with the presence of magnetite, green schist and quartz, and secondly to migmatite, amphibolite, aluminum oxide and ilmenite. The extension of BIF and BIQ is important in the models 2D3/4. These results are in agreement with those done by [15] carried out to the west of our area and [14] to northwest of the study area. This result is acceptable because Cameroon has about $31 \%$ to $35 \%$ iron ore. The future study will be based on the method of Curie point depth (CPD) to analyze the depth of transition of the magnetization by seeking the thermic flux which crosses the rocks, because beyond the Curie depth point, the magnetic effects disappear.

\section{Conclusion}

This study is based on the analysis and interpretation of aeromagnetic data to better define the subsurface structural trends and tectonic of the Djadom-Eta area (southeatern Cameroon). The results achieved about structure dips and di- 
rections help to specify the potential zones in Figure 4 who could deserve attention in next work. The faults, interest zones, dip and orientation are listed in Table 1. With this information, it is possible to determine different geologic constrains including positions, depths, thickness of the sources. The basement rocks are almost affected by nearly vertical normal faults. Covertures faults suggest a link tectonic strong between the basement and the overlying sedimentary column. These knowledge highlights by the multi-scale (HGM) method are preview to $2 \mathrm{D} 3 / 4$ modeling. This study highlights that the $2 \mathrm{D} 3 / 4$ modeling shows the correlation between geological data and magnetic data. Also, propagation of faults and structural analysis of the basement can advance the understanding of the overlying subsurface geological structures for possible BIF system passage and accumulation area as revealed by [5] [14] [15] in the southwestern of this area. Information about the basement faults propagation in the study area will not only enhance our understanding of the regional architecture but can also serve as a guide in the search for BIF and BIQ. Plot of the dip helps to specify the potential zones (see Figure 4). These BIF and BIQ on the geological models (see Figure 5 and Figure 6) are responsible for the magnetization highs. Accordingly, the produced basement map is configured by a set of these faults which are oriented in ESE-WNW and ENE-WSW directions. Also, the average depth values of the magnetic sources range between 375 and $1875 \mathrm{~m}$ as deduced from multiscale methods. Tectonically, the magnetic field exploration is useful for detecting the geometry of the basement rocks and the structures produced by tectonic processes. The structural set up could be interpreted as uplifted and down lifted blocks, fracture and shear zone, which affect the thickness of the shallow. Information about the basement faults propagation allows a better understanding of the architecture but also magnetic mineralization (BIF and BIQ). These points belong to the weakness zones of shearing, fractures and faults. The basement faults propagation area helps to know the direction of dip of the lineaments. The 2D3/4 modeling shows the BIF and BIQ intrude in green schist. The 2D3/4 modeling highlights the supposed Djadom Fault (DF) present in the previous structural study [1].

\section{Conflicts of Interest}

The authors declare no conflicts of interest regarding the publication of this paper.

\section{References}

[1] Yandjimain, J., Ndougsa-Mbarga, T., Bi-Alou, M.B. and Meying, A. (2018) Aeromagnetic Data Modeling for Geological and Structural Mappings over the DJADOM-ETA Area, in the Southeastern Cameroon. International Journal of Geosciences, 9, 354-370. https://doi.org/10.4236/ijg.2018.96022

[2] Toteu, S.F., Penaye, J. and Djomani, P. (2004) Geodynamic Evolution of the Pan-African Belt in Central Africa with Special Y. Reference to Cameroon. Canadian Journal of Earth Sciences, 41, 73-85. https://doi.org/10.1139/e03-079 
[3] Gunn, J.P. (1997) Quantitative Methods for Interpreting Aeromagnetic Data: A Subjective Review. AGSO Journal of Australian Geology \& Geophysics, 17, 105-113.

[4] Gunn, J.P. (1997) Application of Aeromagnetic Surveys to Sedimentary Basin Studies. AGSO Journal of Australian Geologic \& Geophysics, 17, 133-144.

[5] Feumoe, A.N.S., Ndougsa-Mbarga, T., Manguelle-Dicoum, E. and Derek Fairhead, J. (2012) Delineation of Tectonic Lineaments Using Aeromagnetic Data for the South-East Cameroon Area. Geofizika, 29, 175-192.

[6] Meying, A., Ndougsa-Mbarga, T. and Manguelle-Dicoum, E. (2009) Evidence of Fractures from the Image of the Subsurface in the Akonolinga-Ayos Area (Cameroon) by Combining the Classical and the Bostick Approaches in the Interpretation of Audio-Magnetotelluric Data. Journal of Geology and Mining Research, 1, 159-171.

[7] Yandjimain, J., Ndougsa-Mbarga, T., Meying, A., Bi-Alou, M.B., Ngoumou, P.C., Assembe, S.P., Ngoh, J.D. and Owono-Amougou, O.U.I. (2017) Combination of Tilt-Angle and Euler Deconvolution Approaches to Determine Structural Features from Aeromagnetic Data Modeling over Akonolinga-Loum Area (Centre-East, Cameroon). International Journal of Geosciences, 8, 925-947.

https://doi.org/10.4236/ijg.2017.87053

[8] Van Den Hende (1969) Notice Explicative sur la Région Batouri-Ouest Ouest de la Carte Géologique de Reconnaissance à l'échelle du 1/500.000, Direction des Mines et Géologie, Yaoundé, Cameroun, 23.

[9] Tchameni, R., Mezger, K., Nsifa, N.E. and Pouclet, A. (2000) Neoarchean Evolution of the Congo Craton: Evidence from K-Rich Granitoids of the Ntem Complex, Southern Cameroon. Journal of African Earth Sciences, 30, 133-147. https://doi.org/10.1016/S0899-5362(00)00012-9

[10] Bessoles, B. and Lasserre, M. (1977) Le complexe de base du Cameroun. Bulletin de la Société Géologique de France, 19, 1085-1092. https://doi.org/10.2113/gssgfbull.S7-XIX.5.1085

[11] Paterson, Grant, Watson Ltd. (1976) Etudes aéromagnétiques sur certaines Régions de la République Unie du Cameroun. Rapport d'interprétation. ACDI, Toronto, Canada, $190 \mathrm{p}$.

[12] Vicat, J.P. and Bilong, P. (1998) Esquisse géologique du Cameroun. Collection GEOCAM, Presses Universitaires Yaoundé, Yaoundé, 3-11.

[13] Chombong, N.N., Suh, E.C. and Ilouga, C.D.C. (2013) New Detrital Zircon U-Pb Ages from BIF-Related Metasediments in the Ntem Complex (Congo Craton) of Southern Cameroon, West Africa. Natural Science, 5, 835-847.

https://doi.org/10.4236/ns.2013.57101

[14] Ganno, S., Ngnotue, T., Kouankap-Nono, G.D., Nzenti, J.P. and Notsa-Fokeng, M. (2015) Petrology Geochemistry of the Ntem Banded Iron-Formations from Complex Greenstones Belt, Elom Implications Area, Southern Cameroon: For the Origin and Depositional Environment. Geochemistry, 75, 375-387.

https://doi.org/10.1016/j.chemer.2015.08.001

[15] Ganno Njiosseu, S., Tanko, E.L., Moudioh, C., Kouankap-Nono, G.D., Djoukouo-Soh, A., Ngnotué, T. and Nzenti, J.P. (2017) A Mixed Seawater and Hydrothermal Origin of Superior-Type Banded Iron Formation (BIF)-Hosted Kouambo Iron Deposit, Palaeoproterozoic Nyong Series, Southwestern Cameroon: Constraints from Petrography and Geochemistry. Ore Geology Reviews, 80, 860-875. https://doi.org/10.1016/j.oregeorev.2016.08.021

[16] CMC (2012) Exploration Activities in the Djadom Permit 2012-2013 Annual Re- 
port. $41 \mathrm{p}$.

[17] Blakely, R.J. (1996) Potential Theory in Gravity and Magnetic Applications. Cambridge University Press, Cambridge, $441 \mathrm{p}$. https://doi.org/10.1017/CBO9780511549816

[18] Phillips, J.D. (1998) Processing and Interpretation of Aeromagnetic Data for the Santa Cruz Basin-Patagonia Mountains Area, South-Central Arizona. U.S. Geological Survey Open-File Report, 98 p.

[19] Blakely, R.J. and Simpson, R.W. (1986) Approximating Edges of Source Bodies from Magnetic or Gravity Anomalies. Geophysics, 51, 1494-1498. https://doi.org/10.1190/1.1442197

[20] Jacobsen, B.H. (1987) A Case for upward Continuation as Standard Separation Filter for Potential-Field Maps. Geophysics, 52, 1138-1148. https://doi.org/10.1190/1.1442378

[21] El-Wartiti, M. and Zahraoui, M. (2007) Manuel de cartographie. Laboratoire de géologie appliquée. Faculté des Sciences, Université Mohammed V, Agdal, Rabat, 17 p. 